\title{
Detection of adulterated copaiba (Copaifera multijuga Hayne) oil-resins by refractive index and thin layer chromatography
}

\author{
Karol de S. Barbosa, ${ }^{* 1}$ Massayoshi Yoshida, ${ }^{2}$ Veridiana V. Scudeller ${ }^{1}$ \\ ${ }^{1}$ Escola Superior de Ciências da Saúde, Universidade do Estado do Amazonas, Av. Carvalho Leal, 1777, \\ 69065-001 Manaus-AM, Brazil, \\ ${ }^{2}$ Laboratórios de Central Analítica, Centro de Biotecnologia da Amazônia, Av. Gov. Danilo de Matos Areosa, \\ 690, 69075-351 Manaus-AM, Brazil
}

\begin{abstract}
RESUMO: "Deteç̧ão de óleo-resinas de copaíba adulterados através do índice de refração e da cromatografia de camada delgada". Os índices de refração (IR) de oito amostras de óleo resina de copaíba coletadas para este estudo na RDS Tupé variaram de 1,50284 a 1,50786. As placas de cromatografia de camada delgada (CCD) dos óleo-resinas, reveladas com o reagente anisaldeído-ácido sulfúrico, apresentaram um perfil cromatográfico característico, com manchas em lilás escura com várias manchas menores na parte do $\mathrm{R}_{\mathrm{f}}$ baixo e uma grande mancha arredondada, no $\mathrm{R}_{\mathrm{f}}$ alto. Por outro lado, as doze amostras de óleo de copaíba adquiridas no mercado local apresentaram IR entre 1,48176 a 1,50886, e, as placas de CCD apresentaram como perfil característico geral manchas de cor azul, com manchas superpostas menores no $\mathrm{R}_{\mathrm{f}}$ baixo, manchas superpostas maiores com aparência alongada no $R_{f}$ alto e uma mancha arredondada incolor no $\mathrm{R}_{\mathrm{f}}$ intermediário. Dentre os doze óleos adquiridos do mercado, a) três óleo-resinas apresentaram IR e perfil CCD semelhantes aos de amostras de óleo de copaíbas coletadas; b) seis óleos apresentaram o mesmo IR e perfil em CCD do óleo de soja; e, c) três amostras apresentaram IR semelhantes aos da amostra do Tupé, porém com o perfil cromatográfico semelhante à uma mistura de óleo de soja: óleo de copaíba, sendo duas na proporção de 3:1 e uma na proporção de 1:3. Portanto, a determinação do IR e a análise do perfil em CCD podem ser considerados ensaios rápidos e eficientes para a detecção de óleos vegetais em óleo-resina de copaíba.
\end{abstract}

Unitermos: Copaifera multijuga, Fabaceae, óleo-resina de copaíba, índice de refração, cromatografia de camada delgada.

\begin{abstract}
The refractive indices (RI) of the eight samples of copaiba oils, collected for this study at RDS Tupé ranged from 1.50284 to 1.50786 . The thin layer chromatography (TLC) plates of these oils revealed with anisaldehyde-sulphuric acid reagent showed dark lilac stains with several small stains at low $\mathrm{R}_{\mathrm{f}}$ and a large rounded stain at high $\mathrm{R}_{\mathrm{f}}$. On the other hand, the twelve copaiba oils purchased at local markets presented RI between 1.48176 and 1.50886, and the TLC plates, showed as general profile blue stains, with smaller superimposed stains at low $R_{f}$, bigger superimposed stains like elongated stain at high $\mathrm{R}_{\mathrm{f}}$ and a colorless rounded stain at middle $\mathrm{R}_{\mathrm{f}}$. Among 12 purchased oils at local markets, a) three oil-resins presented similar RI and TLC profile to those observed for collected copaiba oils; b) six oils showed same RI and TLC profiles to those observed for soybean oil; c) three samples presented RI near to those showed by copaiba oil-resin, however the TLC profile was near to profile observed for a prepared mixture soybean oil: copaiba oil, two samples with $3: 1$ proportion and one sample with 1:3 proportion. Therefore, the RI determination and the TLC profiles could be considered rapid and efficient procedures for detection of vegetal oil in the copaiba oil-resins.
\end{abstract}

Keywords: Copaifera multijuga, Fabaceae, copaiba oil-resin, refractive index, thin layer chromatography.

\section{INTRODUCTION}

The copaiba oil-resin is one of the most widely phytomedicine used in Brazil, mainly in the North Region, including Amazon. The copaiba oilresin is extensively used in traditional medicine as antiinflammatory and cicatrizing drugs, as well as antitetanic, antiblenorragic and antirheumatic (Cascon,
2004; Tavares et al., 2006; Agra et al., 2007, 2008).

These traditional uses came after indian observation, that injured animals rubbed themselves against the barks of the copaiba trees for the treatment. Thus, the first use of copaiba oil was for treatment of healings and inflammations (Cascon, 2004). Some fractions of Copaifera multijuga oil-resin present anticancer activity in vitro and in vivo assays (Lima et 
al., 2003), and antibacterial activity (Vasconcelos et al., 2008).

The copaiba oil-resin is a product obtained by artisanal procedures. The low availability of this oil in local markets, compelled to the adulteration, since the beginning of the last century, in order to supply the high demand of this product from European and Brazilian markets (Veiga Jr \& Pinto, 2002).

The adulteration of the copaiba oil-resin commercialized in Brazil is made, according to literature (Cascon, 2004), under two modes: a) adding vegetal oil, such as soybean oil, or mineral oil; and b) adding other vegetal oils with a similar density and flavor, but from species of another genera or family (Tappin et al., 2004).

Frequently, it occurs also collection of oilresin of different species of Copaifera, because there are seven different species of Copaifera in the Amazon Rain Forest. These oil-resins present different chemical compositions, but this case is not considered adulterated copaiba oil-resins (Veiga Jr \& Pinto, 2002).

Many techniques for quality control of copaiba oil-resin can be found in the literature. The High Resolution Gas Chromatography (HRGC) shows the occurrence of two groups of compounds in authentic oil-resin used as a reference and it was observed absence of compounds belonging to the volatile group in the commercial samples indicating an adulteration (Tappin et al., 2004).

Some indices, as saponification and acidity values, were investigated for quality evaluation, and it was established that an acidity value above 80 $\mathrm{mg} \mathrm{KOH} / 100 \mathrm{~g}$ oil-resin indicates an adulteration (Vasconcelos \& Godinho, 2002).

The quantification of the sesqui- and diterpenes in commercial oil-resins were also considered in order to detect the adulteration of the samples (Veiga Jr et al., 1997; Biavatti et al., 2006).

This study intents to detect adulterations in the commercial samples of copaiba oil-resin by use of the TLC and refractive index, avoiding undesirable effects, because this important product from the Amazon biodiversity it is frequently used in Brazilian folk medicine for disease treatments.

\section{MATERIAL AND METHODS}

Eight reference oil-resins (C.01, C.02, C.03, C.04, C. 05, C.06, C.07, C.08) were collected according to Leite et al. (2002) by perforation of trunk wood of the Copaifera multijuga Hayne specimens (Figure 1), during the rainy and dry (C.08) seasons at the Reserva de Desenvolvimento Sustentável do Tupé (RDS-Tupé), situated on the left bank of the Rio Negro, $25 \mathrm{~km}$ far from Manaus-AM (Figure 3).

Twelve commercial copaiba oils (P.01 to P.12) were purchased from Mercado Municipal Adolpho Lisboa and from other markets from Manaus-AM. The origins of the samples are showed in Table 1.

The mixtures of soybean oil and copaiba oilresin (C.01) were prepared in proportions of $3: 1 ; 1: 1$ and $1: 3$, respectively.

The refractive indices of these oils were determined on an Abbé type refractometer, manufactured by Optronics Inc., performed in duplicate readings at 20 ${ }^{\circ} \mathrm{C}$.

The chromatographic profiles of the 24 samples were observed on TLC plates $\left(\mathrm{SiO}_{2}, 60, \mathrm{~F} 254\right)$ manufactured by Merck. The TLC plates were eluted with hexane:ethyl acetate 9:1 solvent system. The eluted plates were revealed spraying anisaldehyde-sulphuric acid reagent followed by heating at $120^{\circ} \mathrm{C}$.

\section{RESULTS AND DISCUSSION}

The refractive index of the collected copaiba oils ranged between 1.50184 and 1.50786 (Table 2) at $20{ }^{\circ} \mathrm{C}$. These values are in according to described value of 1.5065 at $24{ }^{\circ} \mathrm{C}$ (Gottlieb \& Iachan, 1945).

The TLC plates of these collected oils revealed with anisaldehyde-sulphuric acid reagent showed dark lilac stains with several small stains at low $\mathrm{R}_{\mathrm{f}}$ and a large rounded stain at high $R_{f^{\prime}}$. The TLC plates of C. 01 and C.04 samples are shown in Figure 3a.

The refractive indices corresponding to the commercial oil-resin samples varied from 1.48176 to 1.50886 (Table 3).

Among twelve commercial samples analyzed, three samples (P.02, P.06, and P.09) showed refractive indices and TLC profiles similar to those observed for the reference oil-resin from RDS-Tupé.

Six commercial samples (P.01, P.03, P.04, P.05, P.07, P.11) presented refractive indices close to those found for soybean oil: 1.47473 . These values agree with those described in the literature which is 1.4737 (Falate et al., 2007).

TLC plates, showed as general profile blue stains, with smaller superimposed stains in the low $R_{f}$, bigger superimposed stains with shape of elongated stain in the high $\mathrm{R}_{\mathrm{f}}$ and a colorless rounded stain in the middle $R_{f^{\prime}}$ In the Figure $3 a$ are shown TLC plates of samples P.01 and P.04.

The refractive indices of soybean oil and collected oil-resin mixtures, respectively in 3:1, 1:1 and 1:3 proportions are show in Table 4.

The TLC profile of soybean oil presents a large light rounded stain in the middle $R_{f}$ and an elongated stain in the high $\mathrm{R}_{\mathrm{f}}$; the $3: 1$ proportion presented small blue stains in the low $\mathrm{R}_{\mathrm{f}}$, a large colorless rounded stain in the middle $\mathrm{R}_{\mathrm{f}}$ an elongated stain in the high $\mathrm{R}_{\mathrm{f}}$; the 1:1 and $1: 3$ proportions presented similar profiles to the $3: 1$ proportion, but different in size of the stains (Figure $3 b$ ).

The commercial samples (P.08, P.10 and P.12) presented refractive indices similar to those found in the collected samples; however the chromatography 
Table 1. Origins and colors of the oil-resins purchased from Manaus-AM markets.

\begin{tabular}{lcl}
\hline Samples & Origin & Color \\
\hline P.01 & Amazon Inland & Light yellow \\
P.02 & Janauacá-AM & Light yellow \\
P.03 & Manaquiri-AM & Light yellow \\
P.04 & Lábrea-AM & Dark yellow \\
P.05 & Lábrea-AM & Light yellow \\
P.06 & Santarém-PA & Light yellow \\
P.07 & Altazes-AM & Light yellow \\
P.08 & Rio Purus AM & Dark yellow \\
P.09 & Lábrea-AM & Light yellow \\
P.10 & Amazon Inland & Light yellow \\
P.11 & Parintins-AM & Light yellow \\
P.12 & Rio Purus AM & Light yellow \\
\hline
\end{tabular}

Table 2. Refractive indices $(\eta \mathrm{D})$ at $20{ }^{\circ} \mathrm{C}$ of oil-resins from C. multijuga collected at the Reserva de Desenvolvimento Sustentável do Tupé, Manaus-AM.

\begin{tabular}{|c|c|}
\hline Reference Samples & $\eta \mathrm{D}_{20}$ \\
\hline C. 01 & 1.50284 \\
\hline C.02 & 1.50585 \\
\hline C.03 & 1.50284 \\
\hline C.04 & 1.50786 \\
\hline C. 05 & 1.50585 \\
\hline C.06 & 1.50585 \\
\hline C.07 & 1.50585 \\
\hline C. 08 & 1.50385 \\
\hline
\end{tabular}

Table 3. Refractive indices $(\eta \mathrm{D})$ at $20^{\circ} \mathrm{C}$ of samples purchased in markets Manaus-AM.

\begin{tabular}{cc}
\hline Samples & $\eta \mathrm{D}_{20}$ \\
\hline P.01 & 1.48477 \\
P.02 & 1.50385 \\
P.04 & 1.48176 \\
P.05 & 1.49180 \\
P.06 & 1.48578 \\
P.07 & 1.50385 \\
P.08 & 1.47875 \\
P.09 & 1.50585 \\
P.10 & 1.50284 \\
P.11 & 1.50886 \\
P.12 & 1.48579 \\
& 1.50485 \\
\hline
\end{tabular}

Table 4. Refractive indices at $20^{\circ} \mathrm{C}$ of mixtures of soybean oil (S.O.) and copaiba oil resin (C.01) collected at the Reserva de Desenvolvimento Sustentável do Tupé, Manaus-AM.

\begin{tabular}{cc}
\hline Proportions & $\eta \mathrm{D}_{20}$ \\
\hline $3: 1$ & 1.48477 \\
$1: 1$ & 1.49180 \\
$1: 3$ & 1.50183 \\
\hline
\end{tabular}

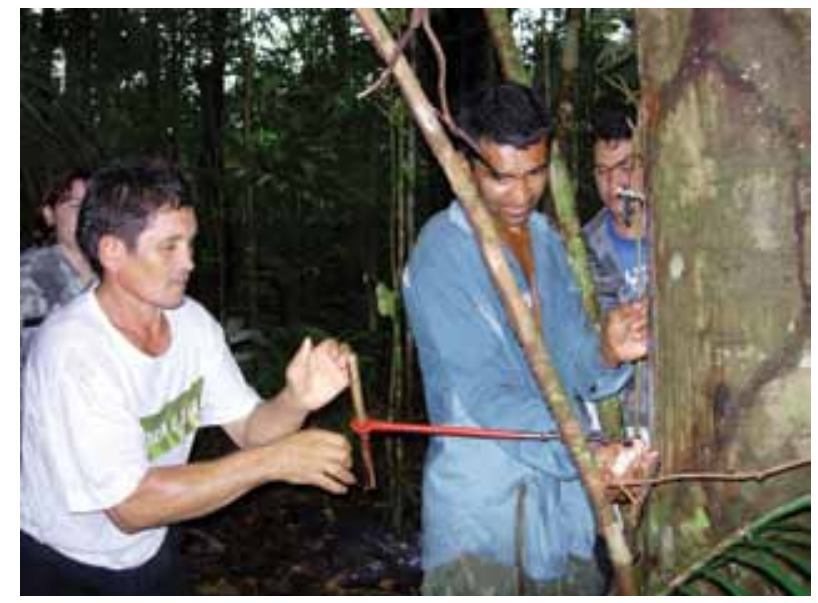

Figure 1. Perforation of Copaifera multijuga tree for oil-resin collection at the Reserva de Desenvolvimento Sustentável do Tupé, Manaus-AM.

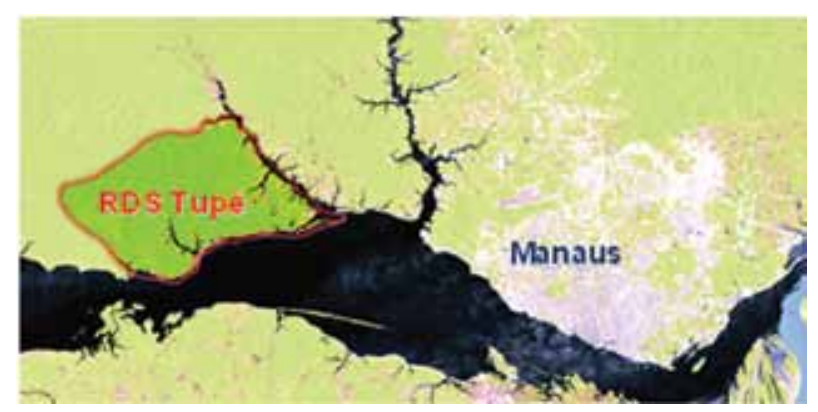

Figure 2. Location of the Reserva de Desenvolvimento Sustentável do Tupé, Manaus-AM.

profiles of P.08 presented similar to 3:1 proportion TLC profile and the P.10 and P.12 samples presented similar profiles to those observed in the 1:3 proportion profile.

According to Shriner (1997), TLC is considered the most useful technique for assessing the purity of organic compounds and Simões \& Sptizer (2004) add that the TLC plate is characteristic for each oil and it allows to confirming to detect fake oils.

TLC as quality control of copaiba oil resin can be easily employed in herbalist laboratories, pharmacies, industries, universities, and etc.

\section{CONCLUSION}

The technique developed to detect adulteration of copaiba oil-resin led to conclusion that the association of refractive indices and thin layer chromatography is efficient, rapid and low cost analyses for product quality control.

\section{AKNOWLEDGEMENTS}

The authors thank to CAPES for the scholarships (KSB), to FAPEAM for the financial support and fellowships (MY), and CNPq for financial 


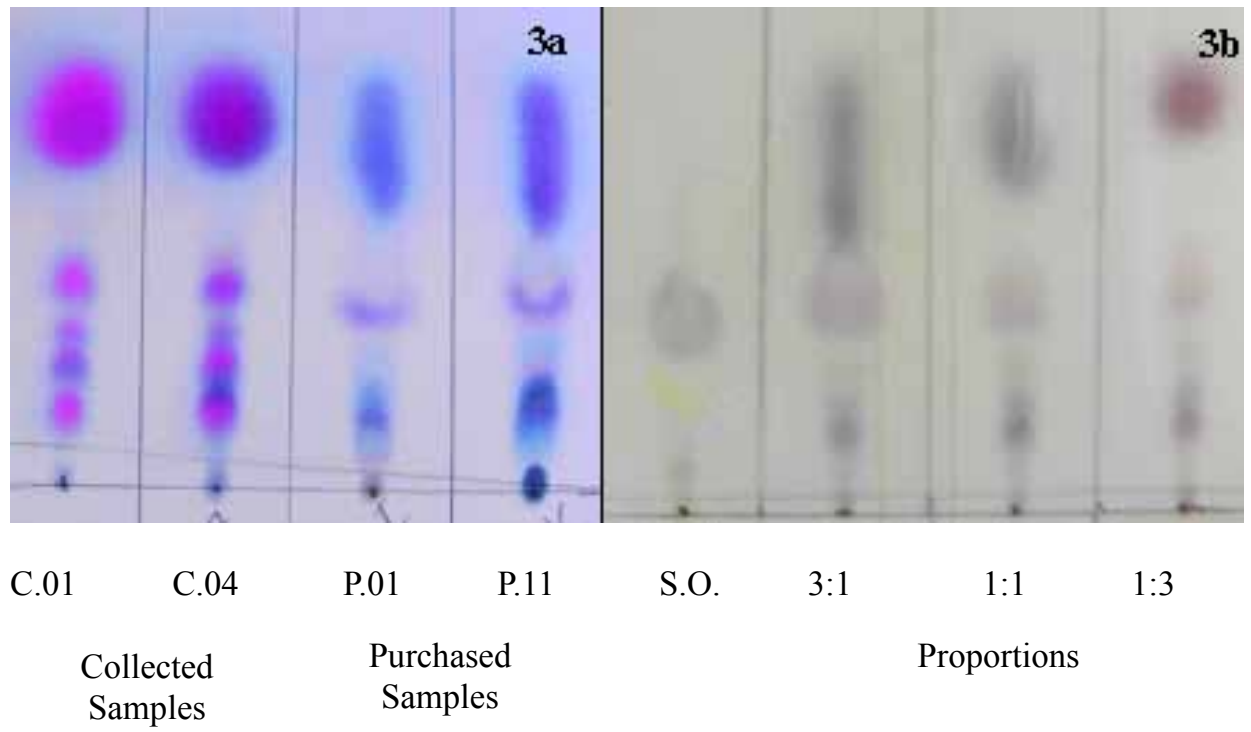

Figure 3. TLC profiles of oils on Silica 60, F254 plates eluted with hexane:ethyl acetate 9:1, revealed with anisaldehydesulphuric acid reagent. 3a. TLC plates of collected samples (C.01 and C.04) and purchased samples (P.01 and P.04). 3b. TLC profile of the samples: soybean oil (SO) and 3:1, 1:1 and 1:3 proportions of S.O.: C.01.

support (VVS); finally to all the participants of the Projeto Biotupé for the sample collection of the copaiba oil-resin.

\section{REFERENCES}

Agra MF, França PF, Barbosa-Filho JM 2007. Synopsis of the plants known as medicinal and poisonous in Northeast of Brazil. Rev Bras Farmacogn 17: 114140.

Agra MF, Silva KN, Basílio IJLD, França PF, Barbosa-Filho JM 2008. Survey of medicinal plants used in the region Northeast of Brazil. Rev Bras Farmacogn 18: 472-508.

Biavatti MW, Dossin D, Deschamps FC, Lima MP 2006. Análise de óleos-resinas de copaíba: contribuição para o seu controle de qualidade. Rev Bras Farmacogn 16: 230-235.

Cascon V 2004. Copaíba: Copaifera spp. In Carvalho, J.C.T. (org) Fitoterápicos antiinflamatórios: Aspectos químicos, farmacológicos e aplicações terapêuticas. Ribeirão Preto, São Paulo, Tecmed, p.221-256.

Falate R, Nike K, Neto PRC, Cação-Jr, E, Muller M, Kalinowski HJ, Fabris JL 2007. Alternative techinique for biodiesel quality control using na optical fiber long-period grating sensor. Quim Nova 30: 1677-1680.

Gottlieb OR, Iachan A 1945. Estudo do bálsamo de copaíba. Rev Quim Ind 163: 20-21.

Leite A, Alexandre A, Rigamonte-Azevedo C, Campos CA, Oliveira A 2002. Recomendações para o manejo sustentável do óleo de copaiba. Rio Branco: UFAC/ SEFE, 38 p. il.

Lima SR, Veiga Jr VF, Cristo HB, Pinto AC, Fernandes PD 2003. In vivo and in vitro studies on the anticancer activity of Copaifera multijuga Hayne and its fractions. Phytother Res 17: 1048-1053.

Simões CMO, Spitzer V 2004. In Simões, C.M.O.; Schenkel, E.P.; Gosmanm, G.; Mello, J.C.P.; Mentz, L.A.; Petrovick, P.R. (org) Farmacognosia da planta ao medicamento. Porto Alegre/ Florianópolis: Editora da UFRGS \& UFSC, p. 461-495.

Shriner RL 1997. The systematic identification of organic comppunds. 7 ed. John Wiley \& Sons, Inc.

Tappin MRR, Pereira JFG, Lima LA, Siani AC, Mazzei JL, Ramos MFS 2004. Análise química quantitativa para a padronização do óleo de copaíba por cromatograma em fase gasosa de alta resolução. Quim Nova 27: 236-240.

Vasconcelos AFF, Godinho OES 2002. Uso de métodos analíticos convencionados no estudo da autenticidade do óleo de copaíba. Quim Nova 25: 1057-1060.

Vasconcelos KRF, Veiga Junior VF, Rocha WC, Bandeira MFCL 2008. Avaliação in vitro da atividade antibacteriana de um cimento odontológico à base de óleo-resina de Copaifera multijuga Hayne. Rev Bras Farmacogn 18 (Supl.): 733-738.

Veiga Jr VF, Patitucci ML, Pinto AC 1997. Controle de autenticidade de óleos de copaíba comerciais por cromatografia gasosa de alta resolução. Quim Nova 20: 612-615.

Veiga Jr VF, Pinto AC 2002. O gênero Copaifera. Quim Nova 25: 273-286. 